Flexible learning spaces: Designed for inclusion?

\title{
LEON BENADE
}

Auckland University of Technology

New Zealand 


\title{
Flexible learning spaces: Designed for inclusion?
}

\begin{abstract}
The idea that the New Zealand education system will cater to all students, regardless of ability, and support them in developing their full potential to the best of their abilities, is enshrined in the famous 1939 Beeby/Fraser statement. Equality of access policy discourse has shifted to emphasise equitable outcomes, focussed increasingly on preparing students for success in the globalised, $21^{\text {st }}$ century knowledge economy. In this context, the design and development of innovative new school buildings and refurbishments of existing facilities have been promoted as a policy that will enable, even bring about, modern pedagogical practices that, in turn, will achieve the stated aim of preparing students for the $21^{\text {st }}$ century global economy. Arguments against retaining traditional single-cell classrooms include their perpetuation of traditional, mainstream ('one-size-fits-all') approaches to teaching and learning, while new, radical building designs hold the promise of enabling the desired 'new' pedagogies. Flexible learning environments encourage and enable teachers to exchange 'front-of-the-room', single teacher presentational approaches for collaborative, dispersed and facilitative styles, often in teams, working with multiple students in shared, common learning spaces. The New Zealand Curriculum has ensured inclusion as an educational principle, and current Ministry of Education policy discourse reminds schools of their commitment to this principle, and specifically links building design and design processes to ensuring inclusivity. So it should be asked whether non-traditional, flexible learning spaces can be inclusive. This article places this question in the context of the historically evolving approach to inclusion in the New Zealand context, and with reference to the 'spatial turn' in recent New Zealand education policy. This turn to enhanced flexibility and innovation has implications for inclusivity, reflected in both Ministry of Education policy discourse and critiques suggesting the exclusionary effects of flexibility. It is argued with reference to Lefebvre that notions of inclusion and exclusion are inherent in social practices that are both superimposed upon material space as much as they are influenced by the design features of that space.
\end{abstract}

\section{Introduction ${ }^{1}$}

This article is underpinned by a critical theoretical orientation that prioritises social relations and materiality over space, that is, following Lefebvre (1991), I recognise in this article the dialectical relationship between the human agents who occupy, dwell in, manipulate, repurpose and resist space, and the artefacts that populate space, including the design elements of the built environment. As Lefebvre contended, space is not a container, simply waiting for humans to inhabit it. By the same token, space will not allow human occupation without also placing its imprint on those same people. Thus, space can both enable and disable; it can facilitate, or hamper, human actions. This article, based as it is on a series of on-going investigations since 2012 of the development of future-oriented pedagogy in non-

\footnotetext{
${ }^{1}$ This article is based on a symposium paper that was presented in the History of Education network of the 2018 European Conference on Educational Research (ECER).
} 
traditional learning environments where boundaries are permeable and uncertain, asks a very simple question: can non-traditional flexible learning environments be inclusive? This article is not concerned with special education needs, but rather with addressing the question of inclusion in a more general sense. In this regard, I find consensus in the scepticism of the 'special needs' and 'special education needs' discourse articulated by Bevan-Brown (2015). Thus, while the content and some of the arguments within this article do reflect on insights from special education needs literature and research, its concern is with whether the educational facilities and learning environments described as 'flexible', 'modern' or 'innovative', are inclusive of all students. The article addresses this question by reference to the national New Zealand context, in the main through historical presentation, policy analysis, and critical consideration of a selection of published literature. It considers what inclusion entails, how it manifests in New Zealand education, evolving over a period since 1877, marking some important changes in direction from an emphasis on equality of access to equity of outcomes, and then contextualising the current emphasis on school architecture. What this latter development could mean for inclusion in a general sense, both positive and negative, is addressed, leaving Lefebvre to support some final reflections in answer to the question.

\section{Inclusion as an underlying principle of New Zealand's education}

New Zealand's education system claims a commitment to providing an inclusive education experience. 'Inclusion' is one of the eight foundational principles of the New Zealand Curriculum (Ministry of Education, 2007). Despite New Zealand's avowed commitment to inclusion, however, international assessment results demonstrate some systemic weaknesses in New Zealand's educational performance. The PISA (Programme for International Student Assessment) rankings and TIMSS (Trends in International Mathematics and Science Study) results reveal unequal learning outcomes being achieved by New Zealand's school-age population, with there being a growing disparity between the top 10 per cent and bottom 10 per cent of New Zealand students (Barback, 2018), and differential achievement of qualifications showing Māori and Pacific Island students lagging behind their Pākehā peers (Carpenter \& Jaramillo, 2014).

The inclusion principle of the The New Zealand Curriculum states:

The curriculum is non-sexist, non-racist, and non-discriminatory; it ensures that students' identities, languages, abilities, and talents are recognised and affirmed and that their learning needs are addressed. (Ministry of Education, 2007, p. 11)

What 'inclusion' means in practice could include:

- Providing all students equal access to mainstream education;

- Recognising the diverse backgrounds of all students;

- Similarly, recognising the individuality of each student;

- Providing each student the opportunity to succeed;

- Actively identifying barriers to learning and achievement, including institutional forms of prejudice, and either removing these, or providing additional resources to 
ensure all students gain equivalent access to education (Equality Challenge Unit, 2013; TKI, nd (a)).

Despite the inclusion principle being enshrined in The New Zealand Curriculum, the only other statement in reference to this principle in the Curriculum is the following: "as all students are individuals, their learning may call for different approaches, different resourcing, and different goals" (Ministry of Education, 2007, p. 39). While this statement may be consistent with the bullet point descriptions of inclusivity above, it is somewhat generic and modestly pitched, with a focus on differential provision. Page \& Davis (2016), make the stronger point that inclusive education has shifted from providing different or additional material to those who do not easily conform with the mainstream, to one where every effort is made to provide those students access to the mainstream curriculum. The intention, they argue, of an inclusive education, is to cater to individual differences without marginalising those requiring support. This view is consistent with the one suggested by Kearney and Bevan-Brown (2014), who locate inclusive education in broader global movements to guarantee the access of all children to education as a basic human right, and efforts to transform "schools and education systems so that they are better able to respond to the needs of all children and young people, particularly those who have historically been excluded or marginalised" (p. 98). These comments align with considerations of social justice.

Traditional views of social justice in education may regard equal access of all to prevailing mainstream education as adequate. This is, however, a weak account, suggesting justice is served when non-mainstream students are successfully assimilated into the mainstream (Bevan-Brown, 2015; Kearney \& Bevan-Brown, 2014). To put it differently, this is a distributive account of social justice in which resources are allocated so all have the same opportunities to participate in the education system. While this concept may imply equal treatment of all, it is more likely to favour those arriving at the starting gate with the advantages of wealth, cultural capital and adequate physical and mental capabilities over those who arrive without some or all of these attributes. That is to say, assimilationist accounts of equality are blind to difference, and do not recognise that all do not achieve equally, even with the opportunity of a common starting-point. As suggested by Kearney and Bevan-Brown (2014) above, systemic transformation is required to enable all those participating in the education process to recognise difference and to take active steps to redress imbalances. Arguably, in a marketised, neoliberal economy (as in the case of New Zealand), assimilationist discourses persist, with the individual being required to overcome personal challenges and be responsible for self-improvement, seen in such discourses as 'self-managed learners', 'ownership of learning' and 'lifelong learning'.

This discussion, and the descriptive bullet-point statements above reflect a tension between a concern to ensure equality of access and treatment for all, and ensuring an equitable outcome for each student. Notably, the first century of educational provision in New Zealand was underpinned by a commitment to the concept of equality, not equity. 


\section{Historical background to the development of equality and equity in New Zealand's education}

The first school was established in New Zealand in 1843, early provision being controlled and managed by various church organisations. From 1853, provincial governments assumed control of education and building of schools, and once the Education Act of 1877 legislated compulsory primary education, central government took control (Simon, 2000). Historically, as the tax contribution to education was equally carried, the Education Department had to provide equal access to schooling for all. This required the development of a national curriculum, as early as the 1880 s (Butterworth \& Butterworth, 1998). For almost 100 years the Education Act of 1877 established the foundations of equality for all through universal education (Cumming \& Cumming, 1978 cited in Selvaraj, 2016).

Under this 1877 Act, a uniform curriculum was offered in the context of a basic, universal, compulsory primary schooling. This curriculum would be extended to include secondary education, though its relevance and the mode of its delivery caused the Secretary for Education in 1928, on the $50^{\text {th }}$ anniversary of the Act, to recall that it "largely...emphasised instruction as distinguished from education; and this involved...[an]...exaltation of the material to be taught...Much that these curricula contained was mere mental lumber, rarely seen or heard of outside of a school" (Caughley, 1928, pp. 38-39).

The impact of the Great Depression (1929-1933) and the election of the first Labour Government in 1935 brought major social, economic and political changes to the country. These changes included a commitment to progressive education, embraced and promoted by then Minister of Education, Peter Fraser, and Clarence Beeby, who later became Director of Education. The view that education should support the individual student, regardless of his or her ability, was expressed in a new mission statement, penned at a meeting of the two men for Fraser's annual ministerial report on education (Selvaraj, 2016).

The Beeby-Fraser formulation stated:

The government's objective, broadly expressed, is that every person, whatever his level of academic ability, whether he be rich or poor, whether he live in town or country, has a right, as a citizen, to a free education of the kind to which he is best fitted, and to the fullest extent of his powers. (Olssen \& Morris Matthews, 1997, p. 9)

Despite its obviously paternalistic tone, this dictum established equal access as a principle of New Zealand schooling for the next fifty years, and under Beeby's influence, elitist structures were challenged, such as rigidly enforced entrance requirements to enter secondary education. Education reforms nonetheless did little for Māori students, whose experience was of an education system that ignored cultural difference and that interpreted 'equality' as assimilation into the prevailing European mainstream (Bevan-Brown, 2015). Nor did education reforms address Māori calls for a wider, more academic curriculum (O'Neill, with Clark and Openshaw 2004b; Openshaw 2009). Instead, a hierarchical schooling system favouring the already powerful (generally European boys) persisted, consigning the majority to vocational pathways. Still, despite these inequities, a discourse developed 
suggesting a period of 'settlement', or agreement between education and state (Codd, $2005 b$ ) across party lines to protect the social-democratic orientation of education (Olssen \& Morris Matthews, 1997; Simon, 2000).

By the late-1970s, global capitalism was in crisis, as Western economies moved from the Fordism of mass production, consumption and full employment to post-Fordist globalisation driven by multi-nationals. As manufacturing shifted to low-wage, unregulated developing economies, so real wage and salary levels fell in developed countries like New Zealand, unemployment increased, and casualisation increased (Brown \& Lauder, 1996). This economic crisis came to challenge the relevance of the Beeby-Fraser vision of educational equality, not to mention the state of equilibrium apparently existing between state and education. Amongst the challenges to this equilibrium was view formed in the mid-1980s by the New Zealand Treasury that education was draining a disproportionate share of tax revenue, requiring therefore measures to curtail this expenditure.

An early initiative of the New Zealand Labour Party government of the 1984-1990 period, was to commission the Picot Taskforce (New Zealand Taskforce to Review Education Administration, 1988) to review the administration of education. This move signalled the start of a reform agenda that would drastically alter the shape and direction of New Zealand's education discourse (Butterworth \& Butterworth, 1998; Codd, 2005c; McKenzie, 1997; Olssen \& Morris Matthews, 1997; Simon, 2000; and Sullivan, 2002). The previously social-democratic, welfarist orientation of New Zealand education required now an "administrative structure...as 'lean' and efficient as possible [to] obtain the best value for the education dollar for the learner" (Butterworth \& Butterworth, 1998, p. 81). The irony of the education reforms of the late 1980s is that neoliberal reformers deployed the rhetoric of the Left to create a pretext for introducing neoliberal reforms by arguing that, despite a half-century commitment to equality, the experience of many, both at school and within society, was of marginalisation and disenfranchisement (Openshaw, 2009; Selvaraj, 2016). The neoliberal reform agenda came to be associated with a shifting of policy discourse from questions of equality of access to equity of outcomes (Butterworth \& Butterworth, 1998; Olssen \& Morris Matthews, 1997; Simon 2000), reflected in the 1989 Education Act.

Arguably, however, the shift to equity of outcomes had less to do with social justice, and more to do with the concerns neoliberal policy-makers had with New Zealand's performance on international league tables. As Kearney \& Bevan-Brown (2014) have pointed out, neoliberal concerns with such tables symbolise the neoliberal individualistic and competitive spirit that is inimical to socially just inclusion. Thus, while espousing the rhetoric of equity, early $21^{\text {st }}$ century New Zealand education reform continued to emphasise the new public management focus on quality, efficiency, economy and effectiveness (Selvaraj, 2016). Simultaneously, New Zealand's education policy in the opening years of the twenty-first century focussed on "creating a knowledge-based economy and preparing young people for the globalization of markets" (Codd, 2005a, p. xv) articulated in the emergent ' $21^{\text {st }}$-century learning' discourse. It is into these policy discourses that the 'spatial turn' to innovative, flexible learning environments has been inserted. 


\section{Contextualisation: The development of modern, flexible and innovative learning spaces}

Globally, $21^{\text {st }}$ century schools and schooling systems are increasingly committed to ensuring that children and school-leavers acquire appropriate skills, including critical thinking and problem solving; collaboration and leadership; agility and adaptability; initiative and entrepreneurialism; effective oral and written communication; accessing and analysing information; and curiosity and imagination (Wagner, 2008, cited in Saavedra \& Opfer, 2012). This skills acquisition underpins the concept of $21^{\text {st }}$-century learning, which reflects fluidity, unpredictability and complexity (Bolstad \& Gilbert, 2012). Teaching and learning for the $21^{\text {st }}$ century prepares young people for engaging in a complex and dynamic world deeply influenced by globalisation and the revolution in digital technology (see, for example, Beetham \& Sharpe, 2013; Loveless \& Williamson, 2013).

The Organisation for Economic Cooperation and Development (OECD) (2009) has questioned 'outmoded' transmission models of teaching in global compulsory education systems that it believes must be reformed. Teachers and school leaders must instead approach their work in radically new ways (for example, Bolstad \& Gilbert, 2012). This transformation is increasingly evident in new technology-rich flexible learning spaces, characterised by large open spaces, permeable boundaries and diverse furnishings emphasising student comfort health and flexibility. Open design encourages flexibility in learning and teaching (Chapman, Randell-Moon, Campbell \& Drew, 2014), and allows collaborative, team teaching, with designers claiming significant educational benefits (Fisher, 2005; Nair, 2011; Tanner, 2009).

New Zealand provides a specific national context for such developments, and particularly over the past five years or so, the New Zealand Ministry of Education has committed itself to a programme of providing significantly upgraded and modernised buildings. As it notes: "We want all schools to have vibrant, well connected, innovative learning environments (ILE) that encourage and support many different types of learning" (2015, "Flexible learning spaces in schools"). Furthermore, the Ministry of Education recognises that teaching styles in New Zealand have become increasingly progressive and student-centred, further encouraging its policy shift towards open schools and learning spaces that better relate classroom design to teachers' practice (MOE, 2017). Arguably then, school facilities' design in New Zealand suggests a prompt to change approaches to teaching and learning, indicating that space and practice are related, at least in the minds of Ministry of Education policy-makers and designers of these facilities.

The OECD defines ILE as "an organic, holistic concept-an eco-system that includes the activity and the outcomes of the learning" (OECD, 2013, p. 11). This broader definition shifts the focus on conceptualising the 'place' of learning from physical facilities to the community, retirement villages, or local business experts. Accordingly, this turns attention to the possibilities for students, teachers, outside experts, content, facilities and technologies to relate (Dumont \& Istance, 2010). 'Flexible Learning Space' (FLS) is the term used by the Ministry of Education to refer to the physical facilities and buildings in which students and teachers work (see MOE, nd, "Talking terminology"), and arguably, this is the space of immediate interest in considering the implementation of the inclusion principle of The New Zealand Curriculum (MOE, 2007). 
While teaching and learning in a FLS may not necessarily differ much from progressive pedagogical practice in a single-cell classroom, the FLS offers pedagogical opportunities and innovative practices not (easily) possible in a single-cell space. This may be for no other reason than what works in a single-cell classroom will not work or be relevant in the markedly different design of a FLS. The pedagogical features particularly relevant to working in a FLS include heightened opportunities for the exercise of student agency and personalised learning; innovative curriculum practices, such as integrated curriculum options and authentic project inquiry-based approaches; and innovative strategies to assess and keep track of student progress. Just as student agency and personalisation are key features of student life in FLS, so collaboration and deprivatisation are central to teachers' lives in FLS. Given these changing circumstances surrounding teaching and learning, what of inclusion, and students requiring additional support and resourcing?

\section{The relationship between flexible learning spaces and inclusivity: The Ministry of Education view}

Apart from the limited definition of the 'inclusion principle' stated in The New Zealand Curriculum (MOE, 2007), the Ministry elsewhere defines inclusion as meaning "all students are welcome and are able to take part in all aspects of school life. Diversity is respected and upheld...Students' identities, languages, abilities, and talents are recognised and affirmed and their learning needs are addressed" (2018, "Defining inclusive education"). The Ministry of Education extends this definition in its resource, Planning an Innovative Learning Environment (TKI, nd. (b)). There it recommends that schools considering flexible learning spaces recognise that the environment influences inclusion, and, coupled with dominant institutional practices in a school, the environment can actively exclude some students. Therefore, "sensitivity to individual differences and learner variability must be a driver for decisions relating to pedagogy, practice, and design of flexible spaces" (TKI, nd. (b)). Schools are directed to several possible strategies outlined on this particular webpage. 'Designing and configuring flexible learning spaces to support the full participation and engagement of all students' is one of these, where the following statement appears: "A flexible learning space will work well for everyone only if it is designed to do so. Design a plan from the outset that includes all students, particularly those experiencing barriers to learning". Two further examples show how the perspective of the Ministry of Education is shaped around creating a relationship between physical design and student learning and inclusion. One is a 'factsheet' stating, "the design of spaces can help student achievement", and "schools must design flexible learning spaces that work for everyone" (2017, "Flexible Learning Spaces Factsheet"). This factsheet actively promotes qualities such as acoustics, lighting, ventilation and furniture as central to creating an inclusive environment for all. The second is one of the key sources of research offered by the Ministry of Education in its advocacy of the spatial turn (Wall, 2016). The central concern of Wall's report is to illustrate a close relationship between building fabric and student outcomes and inclusion. While the factsheet and the report both acknowledge important social practices (such as pedagogy), priority is placed on physical, tangible environmental features as critical to inclusion-but as Blackmore, Bateman, Loughlin, O'Mara, \& Aranda (2011) have suggested, emphasis on tangible environmental factors is a weakness they detected in much learning environments research. 
Of course, the physical designs of ILEs do indeed support students requiring additional help, notably their infusion with rich technology resources, the possibility of concentrating multiple teachers in a learning space, the flexibility for support staff to move within and between spaces, and the actual layout, which can provide better access for students with physical impairments (Page \& Davis, 2016). But none of these advantages can be maximised if teachers are either untrained, or simply revert to default practices, argues Hattie (2015), for whom "changing the shape of buildings does not lead to teachers teaching differently" (p. 17, cited by Page \& Davis, 2016, on p. 89). Arguably then, it may well be that human pedagogical failures have more to do with flexible learning environments not meeting the imperative to be inclusive than their actual material fabric.

\section{Critique, challenges and evidence from the field}

Learning can be more challenging in flexible learning environments for those suffering from a range of auditory, sensory and socio-cognitive issues. A noisy environment is an inhibiting factor in any learning space for all using that space, but especially those who have hearing challenges, or those with Autism Spectrum Disorder (ASD). It is argued that traditionally, New Zealand schools are generally of poor acoustic quality (McLaren \& Page, 2012), and although these weaknesses may be addressed by modern building codes, many learning spaces lack even the most basic treatments, such as carpeting, that would reduce noise. The shifts in teaching and learning towards favouring greater collaboration further reduces the sound quality in learning spaces, compounding the challenges for students with learning disabilities. A common cause of noise is raised voices, causing a spiral of increasing noise, referred to as the 'café effect' (McLaren \& Page, 2012). These authors advocate not only speaking in lower tones to reduce noise, but to educate teachers and students by developing a noise management plan as part of their health and safety measures. This is important not only for the students, but also for the staff working in the school, as "prolonged exposure to noise may...be an occupational issue for many staff..." (p. 209).

Inquiry learning and self-regulation also do not sit easily with students who require support (Page \& Davis, 2016), especially those experiencing ASD and Attention Deficit Hyperactivity Disorder (ADHD) (Schunk \& Bursuck, 2012, cited by Page \& Davis, 2016). ASD students struggle to work well in small teams and groups and lack the social skills required to be effective in these situations. As a result, these students may experience increased anxiety and display challenging behaviours (White, Scahill, \& Ollendick, 2016, cited by Page \& Davis, 2016). This position is supported by the findings of the New South Wales research of Chapman et al. (2014):

Our observations indicated that non-traditional learning classrooms are busy and constantly changing environments that can be overwhelming for some children. While teachers considered that, for the most part, children adapt to and, in some cases, prefer the levels of activity and noise, there was general consensus that such environments are not suited to all students. Importantly, we observed several examples of individual children retreating behind boards, under tables, or into cupboards in order to find a quiet place to read or do their work. (p. 44) 
While current scholarly New Zealand learning environments research critical of the recent policy of building flexible, shared environments is thin and emergent at best, the references above are consistent with a general argument that the physical characteristics of flexible spaces are exclusionary. Persistent community critique in some New Zealand locations, conveyed through the media (print, Internet and social) also commonly point to large spaces as being physically intimidating, allowing students to 'get lost', as permitting too much activity, and particularly, as being overly noisy (examples include Eder, 2018; Jones, 2018).

The critical comments here do not adequately reflect, however, the level of awareness of teachers and schools regarding the challenges facing some students and the active measures taken to manage these challenges. Through gathering data contributing to published studies (Benade, 2016; 2017; 2019) I have noted options including dedicated 'safe' or 'happy' places for ASD students, the creative and flexible use of breakout spaces by teachers and students, and elements of building design that both provide a range of different spaces to suit different children, as well as the installation of a range of acoustic treatments, such as carpeting and generous fibre surfaces on walls. In reference to the suggestion above (noted by Chapman et al., 2014) that students may sit under tables, for example as a means of escape, Charteris, Smardon, \& Page (2018) have had it suggested to them by their research participants that these are creative acts, which these researchers interpreted as appropriation and re-purposing of spaces to the students' advantage. The existence then, of conflicting evidence indicates that it is premature to state unequivocally that bespoke flexible learning spaces and the range of pedagogical practices they make possible are either inclusive, or actively exclude some occupants and users of those spaces. The reality is more complex and messier than this binary implies. Addressing that reality requires the support of theoretical insights, and it is one such insight that I now address.

\section{Lefebvre's comments about inclusion/exclusion}

Recent developments in New Zealand education with regard to building infrastructure suggests, as I indicated, a 'spatial turn', also evident in many countries globally. The problem with policy developments of this kind (another well-known example is Bring Your Own Device) is that they generate high levels of interest and uptake, with minimal corresponding critical consideration, thus they have the potential to become fads (Imms, 2016), and one of the problems with fads is that they allow people and institutions to use language carelessly. The careless use of language further implies or encourages uncritical acceptance or discussion of the phenomenon in question. A very good example of this in the current context is the word, 'environment', which, for the most part in the context this article has considered, is the physical place or space where the work of teachers and students occurs. Indeed, as noted earlier, the Ministry of Education refers to this place as 'Flexible Learning Space (FLS)' (MOE, nd, "Talking terminology"). Yet 'environment' has multiple meanings and usages beyond a physical building. It is therefore appropriate to apply some critical consideration in this discussion to the question of 'space' and its relationship to questions of inclusion and exclusion, and in doing so, I will refer to spatial theorist, Lefebvre.

In The Production of Space (1991), Lefebvre argued for a productive relationship between space and social relations, suggesting the one cannot be understood without the other. Officially sanctioned considerations of 'learning space' in New Zealand (and elsewhere) are 
significantly shaped by the discourses of $21^{\text {st }}$-century learning, and the potential of these cutting-edge designs to support related teaching and learning activities (Imms, 2016). These discourses imply a linear relationship between the qualities of a building and the outcomes policy-makers anticipate will arise from that building. Thus (on this view), post-occupancy evaluations of the new buildings at work need only focus on the effect on student learning of elements of the building fabric (such as light, ventilation and acoustics). Lefebvre's view that space should be theorised as a social construction, and his nuanced treatment (see my discussion, Benade, 2016), of this construction challenges, however, the dominant discourse by shifting the focus from 'objective' measures of the effectiveness of building fabric, furniture and technology. That dominant focus acts only to objectify those who occupy and work in space. Lefebvre also made fleeting, albeit somewhat obscure, reference to inclusion and exclusion (1991). In keeping with his general theme, he regarded inclusion and exclusion as functions of social practice, rather than of space, per se. Yet, space is implicated in the relations of inclusion and exclusion-space does not create this relation alone-it requires social practices too.

Lefebvre's overarching project was to reconcile mental conceptions with the practical lived reality of daily existence in, and use of, spaces-or, in other words, to eradicate the theorypractice divide. The linear view mentioned above is an example of theory (or mental conceptions) being elevated over practical, lived experience-specifically, the view of school designers and bureaucrats at the Ministry conceiving of the physical features within a space as having a direct (and directing) influence on the users of the space. Those who occupy a space do not, however, experience that space as some kind of flat, one-dimensional plane independent of themselves: "they act and situate themselves in space as active participants" (Lefebvre, 1991, p. 294). Coming to terms with space is a learning journeythe 'child' is first aware of his or her body, and later comes to locate and relate that body to the immediate space of daily, lived experience. These spaces of daily experience, such as home or school, offer familiar images and motifs, enabling a later connection to a strange, foreign, and possibly hostile world beyond.

Lefebvre regarded space as both inclusive and exclusive-some spaces are accessible, others not; some are prohibited, others open. Those that are prohibited are perhaps understood as sacred, showing that exclusion goes beyond the physical to include the symbolic - such as the 'fish pond area' of my own high school, strictly 'out of bounds' to all boys, or the 'central staircase' whose use was limited to staff and prefects, consigning the rest to the 'East and West staircases', often places of unspeakable events and hidden terrors for the junior boys. In this sense, inclusion/exclusion is defined in terms of both what is implied, to what does the implying (Lefebvre, 1991). Therefore, discrete physical elements may suggest inclusion (such as a wheelchair ramp), but it is larger social practices (including policy discourse) that condone or promote inclusion/exclusion.

This Lefebvrian-inspired reading of space may be supplemented by a materialist reading, such as suggested by Charteris, Smardon, \& Nelson (2017). Whereas 'agency' as a popular example of ' $21^{\text {st }}$-century pedagogy', is conceived in strictly human terms (children developing agency through self-directed activities, for instance) a materialist reading challenges this anthropocentric understanding, recognising that material, non-human objects may exhibit agency (and, I would argue, influence the agential potential of the 
humans at work in a space). As such, the various relations and processes that occur in a space are then understood as far more fluid and indeterminate than suggested by an instrumentalist or humanist account. Such an account would consider that the physical qualities of space can determine the practices of the users of space, or that human activity can occur regardless of the boundaries and affordances of space. Much more likely it is that the users will re-purpose and re-fashion what they can, and where they can, while also tailoring different practices in response to the dynamics of the space. Thus, students sitting under tables, as reported by Chapman, et al. (2014), is not necessarily a sign of escape, terror or anxiety. My own observations in a number of primary (elementary) schools suggest this is simply an instance of children taking advantage of the flexibility of a non-regimented space. Furthermore, this flexibility enables, for instance, the placement of a pup tent in a learning commons to meet the needs of an anxious child, or the provision of corrals and booths to permit private work by an individual or pairs away from the main area of activity.

In seeking to achieve a unification of the conceived and the lived, Lefebvre suggested that the 'traits' of social space become integrated with "the 'pure' mental form of space" rather than as becoming merely "external superadded content" (1991, p. 292). For Lefebvre, the choice is between thinking about space in terms of discrete elements that can be enumerated, weighed, counted and inventoried, against considering space globally and holistically, paying attention to the relations within space. Thus, it may be argued that both the Ministry of Education and its critics could have it wrong, as both concentrate too heavily on physical elements that can be measured and itemised, ironically to achieve contrary purposes - the one to suggest that physical elements can effect inclusion, the other to suggest that the effects of the physical elements is to exclude some from the learning process. What is missing from both accounts it may be suggested is an adequate grasp on the presence or absence of appropriate social practices, and the holistic experience of the occupants, users and inhabitants of space.

\section{Conclusion}

This article has concerned itself with the underlying question of whether non-traditional learning spaces are 'inclusive'. In understanding inclusivity, it is recognised that students requiring support receive such support over and above the standard educational provisions all receive. The New Zealand education system is committed to this standard, as illustrated by the existence of the 'inclusion principle' being one of eight underpinning The New Zealand Curriculum (MOE, 2007). Yet, historically, the emphasis in New Zealand education has been on getting everyone to the same fence, regardless of whether everyone is able to see over the fence in the first place.

This emphasis, tracked over several generations, especially accentuated by the Beeby-Fraser vision, made some inroads, through policy and curriculum changes, into the structural inequalities that marked New Zealand education, seeking to include as many as possible within the mainstream. Despite some positive advancement, however, inequity remained a constant for girls, Māori, Pasifika, and those who may otherwise be physically or cognitively challenged. Education reform also developed a changing focus, in becoming more concerned with economic outcomes, rather than educational ones-or, it might be said, educational outcomes came to be conflated with economic ones, so that they became 
synonymous. So that appropriate economic outcomes could be attained by the education system, it became important to emphasise similar educational outcomes for all, hence a shift in discourse to equity, rather than equality.

Superimposed onto this evolving educational context is the policy commitment of the New Zealand Ministry of Education to developing non-traditional school facilities, variously referred to as 'Modern Learning Environments', 'Flexible Learning Spaces' and 'Innovative Learning Environments'. Beyond the conceptualisation of these progressive and often cutting-edge facilities, lie the possibilities inherent in them to conduct education differently, and to potentially better serve an increasingly diverse student population. The Ministry of Education argues that the design of these bespoke learning environments can enable inclusion, by virtue of the various physical components of the learning space. Yet there are those who argue that it is precisely these physical components (and some of the evolving pedagogy) that reduce the possibility for them to be inclusive. Both cannot be simultaneously right or wrong, and I have ended this article by arguing, with reference to Lefebvre's notion of space as a social construct, that it is attention to the social practices in space, first and foremost, that makes them inclusive or exclusive-indeed, the building fabric can help, but the social practice of space is foremost. Thus, the answer to my question cannot be sought in simple positive-negative binaries, as even the most modern nontraditional space with its state-of-the-art physical elements can be exclusionary-just as many traditional classrooms over the years have been. What, however, the bespoke, innovative design of a modern school facility does, is to open up possibilities for human relations and pedagogical activities that have simply not existed before-creating opportunities for teachers and school leaders to develop the potential for enhanced inclusion. 


\section{References}

Barback, J. (Feb 14, 2018). Inclusive education - where are we going wrong? Education Review. Retrieved 2 September 2018 from http://educationreview.co.nz/inclusiveeducation-where-are-we-going-wrong/

Beetham, H., \& Sharpe, R. (Eds.). (2013). Rethinking pedagogy for a digital age (2nd ed.). New York, NY: Routledge.

Benade, L. (2016). Is the classroom obsolete in the twenty-first century? Educational Philosophy and Theory, 49(8), 796-807. doi:10.1080/00131857.2016.1269631

Benade, L. (2017). Being a teacher in the 21st century: A critical New Zealand study. Singapore: Springer Nature. doi:10.1007/978-981-10-3782-5

Benade, L. (2019, in press). Effective teaching in flexible learning spaces. In M. Hill \& M. Thrupp (Eds.). The professional practice of teaching ( $6^{\text {th }}$ ed.). Melbourne, Australia: Cengage Learning.

Bevan-Brown, J. (2015). Introduction. In J. Bevan-Brown, M. Berryman, H. Hickey, S. Macfarlane, K. Smiler \& T. Walker (Eds). Working with Māori children with special educational needs. (pp. 3-29). Wellington, New Zealand: NZCER Press.

Blackmore, J., Bateman, D., Loughlin, J., O'Mara, J. \& Aranda, G. (2011). Research into the connection between built learning spaces and student outcomes Literature review, paper No. 22 June. State of Victoria (Department of Education and Early Childhood Development). Retrieved from http://www.education.vic.gov.au

Bolstad, R., \& Gilbert, J., with McDowall, S., Bull, A., Boyd, S., \& Hipkins, R. (2012). Supporting future-oriented learning and teaching: A New Zealand perspective. Report prepared for the Ministry of Education. Wellington, New Zealand: New Zealand Council for Educational Research and Ministry of Education. http://www.educationcounts.govt.nz/publications/schooling/109306

Brown, P., \& Lauder, H. (1996). Education, globalisation and economic development. Journal of Education Policy, 11(1), 1 - 25.

Butterworth, G., \& Butterworth, S. (1998). Reforming education: the New Zealand experience 1984-1996. Palmerston North, New Zealand: Dunmore Press.

Carpenter, V \& Jaramillo, N. (2014). Social justice in education. In A. St. George, S. Brown \& J. O'Neill (Eds). Facing the big questions in teaching: Purpose, power and learning. $2^{\text {nd }}$ ed. (pp. 65-72). Melbourne, Australia: Cengage Learning.

Caughley, J. (1928). The development of the curriculum. In I. Davey (Ed.). Fifty years of national education in New Zealand: 1878-1928. (pp. 36-45). Auckland, New Zealand: Whitcombe \& Tombs Ltd.

Chapman, A., Randell-Moon, H., Campbell, M., \& Drew, C. (2014). Students in space: Student practices in non-traditional classrooms. Global Studies of Childhood 4(1), 3948. doi: 10.2304/gsch.2014.4.1.39

Charteris, J., Smardon, D., \& Nelson, E. (2017). Innovative learning environments and new materialism: A conjunctural analysis of pedagogic spaces, Educational Philosophy and Theory, 49(8), 808-821. doi: 10.1080/00131857.2017.1298035

Charteris, J., Smardon, D., \& Page, A. (2018). Spatialised practices in ILEs: Pedagogical transformations and learner agency. In L. Benade \& M. Jackson (Eds.). Transforming education: Design \& governance in global contexts, (pp. 19-32). Singapore: Springer Nature. 
Codd, J. (2005a). Is there a 'Third Way' for education policy? In J. Codd \& K. Sullivan (Eds.), Education policy directions in Aotearoa New Zealand (pp. xiii-xviii). Southbank, Vic, Australia: Thomson Dunmore Press.

Codd, J. (2005b). Politics and policy making in education. In P. Adams, K. Vossler \& C. Scrivens (Eds.), Teachers' work in Aotearoa New Zealand (pp. 28-38). Southbank, Vic, Australia: Thomson Dunmore Press.

Codd, J. (2005c). Teachers as 'managed professionals' in the global education industry: the New Zealand experience. Educational Review, 57(2), 193-206.

Dumont, H \& Istance, D. (2010). Analysing and designing learning environments for the $21^{\text {st }}$ century. In H. Dumont, Istance, D \& Benavides, F. (Eds.), The nature of learning: Using research to inspire practice (pp. 19-34). Paris, France: Organisation for Economic Cooperation and Development Publishing. doi: http://dx.doi.org/10.1787/9789264086487-3-en

Eder, J. (2018, May 2). 'My child is not a guinea pig': Parents want proof 'experimental' classrooms work. The Marlborough Express. Retrieved 2 Feb 2019 from https://www.stuff.co.nz/national/education/101994384/my-child-is-not-a-guineapig-parents-want-proof-experimental-classrooms-work

Equality Challenge Unit. (2013). Equality and diversity for academics: Inclusive practice. https://www.strath.ac.uk/media/ps/sees/equality/e-and-d-for-academics-factsheetinclusive-practice.pdf

Fisher, K. (2005). Research into identifying effective learning environments. Retrieved from http://www.oecd.org/education/innovationeducation/centreforeectivelearningenvironmentscele/37905387.pdf

Imms, W. (2016). New Generation Learning Environments: How can we find out if what works is working? In W. Imms, B. Cleveland, \& K. Fisher (Eds). Evaluating learning environments: Snapshots of emerging issues, methods and knowledge. (pp. 21-34). Rotterdam, The Netherlands: Sense Publishers.

Jones, K. (2018, Jul 21). Are modern learning environments working in our schools? Nelson Mail. Retrieved 2 Feb 2018 from https://www.stuff.co.nz/nelsonmail/news/105196164/are-modern-learning-environments-working-in-our-schools

Kearney, A. \& Bevan-Brown, J. (2014). Inclusive education: Addressing the challenge of equity in education. In A. St. George, S. Brown \& J. O'Neill (Eds). Facing the big questions in teaching: Purpose, power and learning. $2^{\text {nd }}$ ed. (pp. 97-103). Melbourne, Australia: Cengage Learning.

Lefebvre, H. (1991). The production of space. (D. Nicholson-Smith, trans.). Malden, MA: Blackwell.

Loveless, A., \& Williamson, B. (2013). Learning identities in a digital age: Rethinking creativity, education and technology. New York, NY: Routledge.

McKenzie, D. (1997). The cult of efficiency and miseducation: Issues of assessment in New Zealand schools. In M. Olssen \& K. Morris Matthews (Eds.), Education policy in New Zealand: the 1990s and beyond (pp. 47-64). Palmerston North, New Zealand: Dunmore Press.

McLaren, J. \& Page, W.H. (2012). Noise issues in inclusive learning environments. In Centre of Excellence for Research in Inclusive Education, (pp. 204-219). Auckland, New Zealand: Dunmore Press. 
Mealings, K., Buchholz, J., Demuth, K., \& Dillon, H. (2015). Investigating the acoustics of a sample of open plan and enclosed Kindergarten classrooms in Australia. Applied Acoustics, 100(2015), 95-105. doi: http://dx.doi.org/10.1016/j.apacoust.2015.07.009

Ministry of Education [MOE]. nd. Talking terminology. Retrieved 2 September 2018 from http://ile.education.govt.nz/talking-terminology/

Ministry of Education [MOE]. (2007). The New Zealand Curriculum. Wellington, New Zealand: Learning Media Limited. Available from http://nzcurriculum.tki.org.nz/TheNew-Zealand-Curriculum

Ministry of Education [MOE]. (2015). Flexible learning spaces in schools. Retrieved 2 September 2018 from http://www.education.govt.nz/school/property/stateschools/design-standards/flexible-learning-spaces/

Ministry of Education. [MOE] (2017). Flexible learning spaces: How the design of spaces can help student achievement

https://www.education.govt.nz/assets/Documents/Primary-

Secondary/Property/School-property-design/Flexible-learning-spaces/FLS-How-thedesign-of-spaces-can-help-student-achievement.pdf

Ministry of Education. [MOE] (2018). Inclusive education. Retrieved 2 September 2018 from https://www.education.govt.nz/school/running-a-school/inclusive-education/

Nair, P. (2011). The classroom is obsolete: It's time for something new. Education Week. $\begin{array}{llll}\text { Retrieved } 2018, & \text { September }\end{array}$ https://www.edweek.org/ew/articles/2011/07/29/37nair.h30.html

New Zealand Taskforce to Review Education Administration. (1988). Administering for excellence: effective administration in education. Wellington, New Zealand: The Taskforce.

Olssen, M., \& Morris Matthews, K. (1997). Introduction. In M. Olssen \& K. Morris Matthews (Eds.), Education policy in New Zealand: the 1990s and beyond (pp. 7-46). Palmerston North, New Zealand: Dunmore Press.

O'Neill, A., with Clark, J., \& Openshaw, R. (2004). Mapping the field: An introduction to curriculum politics in Aotearoa/New Zealand. In A. O'Neill, J. Clark \& R. Openshaw (Eds.), Reshaping culture, knowledge and learning? Policy and content in the New Zealand Curriculum Framework (Vol. One, pp. 25-46). Palmerston North, New Zealand: Dunmore Press.

Openshaw, R. (2009). Reforming New Zealand secondary education: The Picot Report and the road to radical reform New York, NY: Palgrave Macmillan.

Organisation of Economic Cooperation and Development [OECD]. (2009). Creating effective teaching and learning environments: First results from TALIS. Retrieved from https://www.oecd.org/education/school/43023606.pdf

Organisation for Economic Cooperation and Development [OECD]. (2013). Innovative Learning Environments. Retrieved 2 September 2018 from http://www.oecd.org/education/ceri/innovativelearningenvironmentspublication.ht $\underline{\mathrm{m}}$

Page, A. \& Davis, A. (2016). The alignment of Innovative Learning Environments and inclusive education: How effective is the new learning environment in meeting the needs of special education learners? New Zealand Journal of Teachers' Work, 13(2), 81-98. doi: https://doi.org/10.24135/teacherswork.v13i2.79 
Saavedra, A. \& Opfer, D. (2012). Learning 21st-century skills requires, 21st-century teaching. Phi Delta Kappan, 94(2), 8-13. doi: https://doi.org/10.1177\%2F003172171209400203

Selvaraj, J. (2016). Inclusion in New Zealand secondary schools: Policy and practice. Doctoral thesis, University of Auckland, Auckland, New Zealand. Retrieved from https://researchspace.auckland.ac.nz/bitstream/handle/2292/29647/whole.pdf?seq $\underline{\text { uence }=2}$

Simon, J. (2000). Education policy change: historical perspectives. In J. Marshall., E. Coxon., K. Jenkins. \& A. Jones (Eds.), Politics, policy, pedagogy: education in Aotearoa/New Zealand (pp. 25-70). Palmerston North, New Zealand: Dunmore Press.

Sullivan, K. (2002). Editorial: Education policy and practice in contemporary Aotearoa-New Zealand. McGill Journal of Education, 37(1), 6-12.

Tanner, C. K. (2009). Effects of school design on student outcomes. Journal of Educational Administration, 47, 376-394. doi:10.1108/09578230910955809

Te Kete Ipurangi [TKI]. (nd) (a). Developing an inclusive classroom culture. Retrieved 2 September 2018 from http://inclusive.tki.org.nz/guides/developing-an-inclusiveclassroom-culture/

Te Kete Ipurangi [TKI]. (nd) (b). Planning innovative learning environments. Retrieved 2 September 2018 from http://inclusive.tki.org.nz/guides/ile/

Wall, G. (2016). The impact of physical design on student outcomes. Report commissioned by the Ministry of Education. Available at http://www.education.govt.nz/assets/Documents/PrimarySecondary/Property/School-property-design/Flexible-learning-spaces/FLS-Theimpact-of-physical-design-on-student-outcomes.pdf 